\title{
Diversity and Abundance of Arbuscular Mycorrhizal Fungi Under Different Plant and Soil Properties in Sidama, Southern Ethiopia
}

\author{
Beyene Dobo 1, ", Fassil Asefa ${ }^{2}$, Zebene Asfaw ${ }^{3}$ \\ ${ }^{1}$ Department of Natural Resources Management and Environmental Sciences, Haramaya University, Haramaya, Ethiopia \\ ${ }^{2}$ Department of Microbial, Cellular and Molecular Biology, Addis Ababa University, Addis Ababa, Ethiopia \\ ${ }^{3}$ Wondo Genet College of Forestry and Natural Resources, Hawassa University, Hawassa, Ethiopia \\ Email address: \\ beyeneashl@yahoo.co.uk (D. Beyene), asefafasi12013@gmail.com (A. Fassil),zebeneasfaw@yahoo.co.uk (A. Zebene) \\ ${ }^{*}$ Corresponding author
}

\section{To cite this article:}

Beyene Dobo, Fassil Asefa, Zebene Asfaw. Diversity and Abundance of Arbuscular Mycorrhizal Fungi Under Different Plant and Soil Properties in Sidama, Southern Ethiopia. Advances in Bioscience and Bioengineering. Vol. 4, No. 3, 2016, pp. 16-24.

doi: 10.11648/j.abb.20160403.11

Received: June 13, 2016; Accepted: July 1, 2016; Published: July 21, 2016

\begin{abstract}
In Sidama, agroforestry represents land-use systems with deliberate management of multipurpose trees and shrubs that grow in intimate association with annual and perennial agricultural crops and/or livestock. The interaction of microbiota with the trees, shrubs and crops make the system fertile, productive and sustainable. One of the beneficial microbiota which has symbiotic association with most of the plants in agroforestry is arbuscular mycorrhizal fungi (AMF). In November and December of 2012, root and rhizosphere soil samples of 21 plant species from nine peasant associations (PAs)(villages within districts where 300-500 families live) were collected from the agroforestry practices in Sidama of Southern Ethiopia for the determination of diversity and abundance of AMF under selected soil parameters and plant species density. Findings on the diversity of AMF based on soil properties showed that at moderate to low $\mathrm{P}$ and $\mathrm{N}$ concentrations the rate of AMF root colonization and spore density was high in comparison with the rhizosphere soils with the highest $\mathrm{P}$ and $\mathrm{N}$ concentration. The highest percentage of total AMF colonization was recorded for shade trees Millettia ferruginea (84\%) and Erythrina brucei (80\%) followed by intercropped perennial crops Ensete ventricosum (86\%), Catha edulis $(85 \%)$ and Coffea arabica $(80 \%)$ and the lowest percentage AMF colonization was recorded for Rhamnus prinoides $(53 \%)$ and Colocasia esculenta (52\%). Though found in almost all homegarden agroforestry practices and with broad coverage in Sidama agroforestry, some crops and vegetables such Brassica integrifolia and Cucurbita pepo, grown intercropped were found to be non-mycorrrhizal as none of the AMF structures were recorded. The highest number of AM spore population was recorded in rhizosphere soils of Croton macrostachyus (1066 \pm 19.33$)$ and Catha edulis (1054 \pm 53.12$)$ and the lowest spore density was recorded for Dioscorea alata (100.00 \pm 2.89$)$ spore per $100 \mathrm{~g}$ of dry soil. The percentage fungal colonization in any individual plant species and spore population in the rhizosphere soils of that species did not correlate to each other and percentage AM root colonization and spore density of all plants in the agroforestry of Sidama were found significantly different at $\mathrm{P}<0.05$ level.
\end{abstract}

Keywords: AMF, Rhizosphere, Parameters, Colonization, Density

\section{Introduction}

Forests are cleared for agriculture and settlement in different parts of Ethiopia. Agroforestry is an age old traditional practice which gradually replaced forests. It is a sustainable management system for land that combines agricultural crops, trees, forest plants and/or animals simultaneously or sequentially, and applies management practices that are compatible with the cultural patterns of the local population [1]. It is practiced on Homegarden [24] and [40], cropland [31], and forest lands [10]; [39]. Although the 
role of agroforestry in conserving biological diversity is being appreciated in many parts, the sustainability of these practices is a major concern in Ethiopia.

Low soil fertility, acidity and deficiency in major nutrients such as phosphorus and nitrogen are some of the problems related to successful agroforestry systems. The conversion of forest to different agricultural systems causes loss of plant species that expose the soil to water and wind erosion. Besides, the removal of plant species from forests and agroforests may be accounted for the loss of biodiversity, not only of plants, but also the microbiota important for the soil health as a whole. Therefore, maintenance of floristic diversity in agroforestry is number one crucial condition for sustainable productivity of the agroforests. One of such situations is planting of mycorrhizal seedlings that can be a good measure to increase the yield of the plants for the sustainable management for land that will increase the overall production.

Arbuscular mycorrhizal fungi are widespread and symbiotic copious members of the soil biota, a generally acknowledged key factor in agricultural ecosystem functioning and sustainability [39]. These symbiotically associated fungi play an important role to the plants in agroforestry practices by enhancing establishment and growth, increasing nutrient and water uptake, maintaining diversity by accelerating the ability of host plants to compete for resources, contributing to efficient recycling of nutrients and thus to long term stability and stabilization of the soil $[16,35]$. AMF are widespread in tropical soils and associate with a wide range of plant species, including most commercial crops and trees [6, 34]. They are keystone organisms and form an interface between soils and plant roots, and are sensitive to changes in soil physicochemical properties and plant conditions [28].

Under the insufficient concentration of nutrients in the root zone of plants, exploring further in the soil with its extended extra radical hyphae, AMF supply phosphorus, macro and micro soil nutrients to roots which has symbiosis with AMF. In these symbiotic associations both partners benefit from each other under certain conditions $[4,8,19,30]$. Fungi take some organic matter and carbohydrates from the plant. In return, AMF supply nutrients such as phosphorus, nitrogen $(\mathrm{N})$, calcium $(\mathrm{Ca})$, copper $(\mathrm{Cu})$, manganese $(\mathrm{Mn})$, sulphur $(\mathrm{S})$ and zinc $(\mathrm{Zn})[26,34]$. But when the soil is rich in necessary nutrients, plants may not waste more energy for the association with AMF and go for the cheapest source of energy, and individual plant species and plant communities in natural and farming systems affect the distribution and diversity of AMF species [7, 17].

Therefore, according to the previous investigators, AMF spore density, diversity and rates of root colonization are dependent on soil physicochemical properties [22] and plant species density and richness [1]. Though there are some research reports [40] on mycorrhizal association of agroforestry trees, information is scarce on spore density and diversity of AMF based on soil parameters and type of plant species density and richness in Sidama agroforestry. Therefore, the objective of the present investigation is to study diversity of AMF based on selected soil parameters and plant species density in selected sites of Sidama agroforestry practices.

\section{Materials and Methods}

\subsection{Sampling Site}

This study was conducted in Sidama Administrative region of Southern Ethiopia during dry season in November and December of 2012. It lies between 06 $45^{\prime} 33^{\prime \prime}$ and $06^{\circ} 54^{\prime} 713^{\prime \prime} \mathrm{N}$ and $038^{\circ} 27^{\prime} 432^{\prime \prime}$ and $038^{\circ} 31^{\prime} 788^{\prime \prime} \mathrm{E}$ and 1740 to $2135 \mathrm{~m}$ above the sea level. The study area is characterized by a moist to sub-humid warm sub-tropical climate with annual rainfall of $1000-1800 \mathrm{~mm}$ and mean annual temperature of $15-20^{\circ} \mathrm{C}$. The main agricultural system in the region is the Tree-enset-coffee based homegarden agroforestry systems commonly practiced in Southern Ethiopia. The study was undertaken in 36 home gardens located in 9 peasant association (PAs, smallest Ethiopian administrative unit, where 300-500 families live) distributed over two woredas or district. Each woreda (district) has 40 60 PAs where these agroforestry systems are practiced. In this study, we selected only 9 PAs (Table 1) because these PAs are located at closest proximity to the original forest relics from where the agroforestry practices were emerged. From each PAs, 4 homegardens were selected randomly and soil and root samples were collected from 23 commonly occurring plant species in selected agroforestry practice (Table 2).

Table 1. Geographical location and altitudinal ranges of the Peasant Associations (PA's).

\begin{tabular}{|c|c|c|c|c|}
\hline No & Study site (PAs) & Latitude & Longitude & Altitude \\
\hline 1. & Ferro I & $06^{\circ} 46^{\prime} 30^{\prime \prime} \mathrm{N}$ & 038²9’00'Е & $1795-1896$ \\
\hline 2. & Ferro II & $06^{\circ} 49^{\prime} 602^{\prime \prime} \mathrm{N}$ & $038^{\circ} 29^{\prime} 135^{\prime \prime} \mathrm{E}$ & $1860-1940$ \\
\hline 3. & Halekena & $06^{\circ} 45^{\prime} 333^{\prime \prime} \mathrm{N}$ & $038^{\circ} 27^{\prime} 432^{\prime \prime} \mathrm{E}$ & $1740-1825$ \\
\hline 4. & Taramesa & $06^{\circ} 086^{\prime} 055^{\prime \prime} \mathrm{N}$ & $038^{\circ} 45^{\prime} 605^{\prime \prime} \mathrm{E}$ & $1745-1868$ \\
\hline 5. & Tellamo & $06^{\circ} 083^{\prime} 629^{\prime \prime} \mathrm{N}$ & $038^{\circ} 48^{\prime} 489^{\prime \prime} \mathrm{E}$ & $1825-1906$ \\
\hline 6. & Gonowagoda & $06^{\circ} 084^{\prime} 609^{\prime \prime} \mathrm{N}$ & 038॰50’916”Е & $1855-1990$ \\
\hline 7. & AbelaLida & $06^{\circ} 54^{\prime} 993 ” \mathrm{~N}$ & 038²9’317'E & $1945-1960$ \\
\hline 8. & Galakohireye & $06^{\circ} 54^{\prime} 864^{\prime \prime N}$ & 038³0’315’'E & 2006-2011 \\
\hline 9. & Arossa & $06^{\circ} 54^{\prime} 713^{\prime \prime} \mathrm{N}$ & $038^{\circ} 31^{\prime} 788^{\prime \prime} \mathrm{E}$ & $2111-2135$ \\
\hline
\end{tabular}


Table 2. Plant species present in Sidama agroforestry systems the time of sampling.

\begin{tabular}{|c|c|c|c|c|}
\hline S. No & Latin names & Family & Amharic & Sidamigna \\
\hline 1. & Ensete ventricosum (Welw.) Cheesman) & Musaceae & Enset & Wesse \\
\hline 2. & Catha edulis (vahl.) Forssk. exEndl & Celastraceae & Khat & Khat \\
\hline 3. & Millettia ferruginea Hochst & Fabaceae & Birbira & Hengedicho \\
\hline 4. & Erythrina brucei Schweinf & Fabaceae & Korch & Wellako \\
\hline 5. & Cordia africana Lam. & Boraginaceae & Wanza & Wadicho \\
\hline 6. & Croton macrostachyus (HochstExDel.) & Euphorbaceae & Bisana & Mesincho \\
\hline 7. & Prunus africana (Hook. f.) Kalkm. & Rosaceae & TikurInchet & Garbicho \\
\hline 9. & Persea americana Mill. & Lauraceae & Avokado & Abukato \\
\hline 10. & Mengifera indica $\mathrm{L}$. & Anacardiaceae & Mango & Mango \\
\hline 11. & Saccharum officinarum L. & Poaceae & Shenkorageda & Shenkora \\
\hline 12. & Ricinus communis L. & Euphorbiaceae & Castor & Qenboo \\
\hline 13. & Coffea arabica $\mathrm{L}$. & Rubiaceae & Coffee & Buna \\
\hline 14. & Zea mays L. & Poaceae & Bokolo & Bedela \\
\hline 15. & Phaseolus vulgaris L. & Fabaceae & Common bean & Wahe \\
\hline 18. & Cucurbita pepo L. & Cucurbitaceae & Pumpkin & Baqula \\
\hline 19. & Brassica integrifolia (West) O. E. schulz & Brassicaceae & Kale & Shana \\
\hline 20. & Cappisicum annuиm $\mathrm{L}$. & Solanaceae & Chilly & Mitmita \\
\hline 21. & Rhamnus prinoides L' herit & Rhamnaceae & Gesho & Taddo \\
\hline 22. & Dioscorea alata $\mathrm{L}$. & Dioscoraceae & Boyna & Bohe \\
\hline 23. & Colocasia esculenta (L.) Schoot. & Araceae & Godere & Qolchoma \\
\hline
\end{tabular}

\subsection{Soil Sampling and Analysis}

Rhizosphere soils from under the canopy of the 23 plant species which included trees, crops and vegetable species were collected during dry season (November-December) in year 2012 from each sampling site (PAs). Soil sample collection was carried out at four $10 \mathrm{~m} \times 10 \mathrm{~m}$ quadrats from each PAs. The soil was sampled to a depth of $0-15 \mathrm{~cm}$ in 828 sampling points using a soil auger. A composite soil sample of $500 \mathrm{~g}$ was collected from each plant species. In total $(23 \mathrm{x}$ $9 \times 4$ ) samples were collected for analysis from all the 9 PAs (sampling sites), i. e. $23 \times 4$ samples from each sampling site. The soil samples were air-dried at room temperature for two weeks and preserved at $4^{\circ} \mathrm{C}$ for analysis of soil physicochemical properties, AMF spore abundance and AMF diversity. About $0.5 \mathrm{mg}$ of fine root samples from each plant were also collected, washed with tap water, preserved in $50 \%$ ethanol, and stored at $4^{\circ} \mathrm{C}$ for percentage root colonization analysis.

Soil analysis were undertaken at the Southern Nations, Nationalities and Peoples Region (SNNPR) Soil Laboratory and Debrezeite Agricultural Research Center following standard procedures and methods: Soil textural fractions were analyzed following the hydrometric method after removing organic matter using $\mathrm{H}_{2} \mathrm{O}_{2}$ and dispersing the soils with sodium hexameta-phosphate [2]. Soil $\mathrm{pH}$ was determined by potentiometric methods using 1:2.5 soil: water ratio. Soil organic carbon (SOC) was determined by the Walkley-Black oxidation method [33]). Total nitrogen (TN) was determined using the Kjeldahl distillation method [5], and available phosphorous (AP) was determined using Olsen's extraction method (UV/visible Spectrometer, Lambda EZ 201) [25]. Available potassium (Av. K) was determined by Sodium Acetate method [18].

\subsection{Root Colonization}

The root pieces collected and preserved were stained according to [27] with some modifications. The root pieces were cleared in $10 \% \mathrm{KOH}$ solution for $15-20$ minutes at $90^{\circ} \mathrm{C}$ in a boiling water bath. Then, they were rinsed in water several times and acidified with $1 \% \mathrm{HCI}$ solution. Pigmented roots were bleached in $\mathrm{H}_{2} \mathrm{O}_{2}$ for about 20 minutes and again washed with water. Finally the root segments were stained for 10 minutes in $0.05 \%$ trypan blue at $90^{\circ} \mathrm{C}$ for about 10 minutes and subsequently distained at room temperature in acidic glycerol.

The stained root segments were mounted in acidic glycerol on slides. The roots were then observed under the compound microscope (200x objective magnification). The presence of colonization in a root segment was recorded if hyphae (only), vesicle or arbuscule were found. About 100-150 intersections were examined for each sample. Total root colonization was calculated using the following formula: \% Colonization $=$ Total number of positive segments/Total number of segments studied $\times 100$.

\subsection{Spore Population}

From each soil sample $100 \mathrm{~g}$ soil was mixed in a 2 liter capacity beaker containing 1.5 liter of water. The soil in water was agitated by stirring vigorously by hand and left to settle down for about five minutes. The suspension was then sequentially $(480,100,50 \& 38 \mu \mathrm{m})$ sieved following the wet sieving and decanting method [13]. The last pellet $(38 \mu \mathrm{m})$ was suspended in $60 \%$ sucrose solution and thoroughly mixed and centrifuged at 2000rpm for 1 minute and the spores were rinsed carefully with tap water and transferred into plastic petri-dishes.

The AMF spores and sporocarps of each sample were 
counted under $4 \mathrm{x}$ stereomicroscope. The spore densities were expressed as the numbers of spores and sporocarps per $100 \mathrm{~g}^{-}$

${ }^{1}$ of dry soil. Representative Morphospecies were mounted on slides with polyvinyl-lactic acid-glycerol (PVLG) or PVLG mixed with Melzer's reagent $(1: 1 \mathrm{v} / \mathrm{v})$. Taxonomic differentiation was made based on the descriptions of the International Culture Collection of Vesicular/Arbuscular Mycorrhizal Fungi (http://invam.caf.wvu.edu; 2005), and following descriptions by [32].

\subsection{Statistical Analysis}

Data on spore abundance and root colonization was log (x) and arcsine (the inverse sine of the square root of the proportion) transformed using PAST3 (ver. 1.0.0.0) and SPSS software package (version 20.0) respectively, prior to analysis to meet assumptions of ANOVA such as normality and homogeneity of variance.

Significance of differences in AM fungal spore abundance and percentage of root colonization between the samples was tested using Duncan's Multiple Range Test at $p<0.05$ after one-way analysis of variance (ANOVA) with the SPSS software package (version 20.0) [12]. Pearson's correlation analysis was used to study the relationship between AMF and soil parameters.

\section{Results}

\subsection{Soil Physicochemical Properties Under Different Plant Species}

Table 3. Rhizosphere soil chemical properties of plants.

\begin{tabular}{|c|c|c|c|c|c|c|}
\hline S. No & Plant species & $\mathrm{pH}\left(\mathrm{H}_{2} \mathrm{O}\right)$ & OC\% & TN\% & AP (Olson) (mg/kg) & Kemol (+) /kg \\
\hline 1. & Ensete ventricosum (Welw.) Cheesman) & $6.49 \pm .12 b$ & $2.41 \pm .23 \mathrm{a}$ & $0.26 \pm 0.02 \mathrm{c}$ & $10.20 \pm 1.3 \mathrm{e}$ & $0.61 \pm 0.33 \mathrm{a}$ \\
\hline 2. & Catha edulis (vahl.) Forssk. exEndl & $5.02 \pm 0.00 \mathrm{a}$ & $2.04 \pm 0.02 \mathrm{a}$ & $0.23 \pm 0.00 \mathrm{~b}$ & $7.12 \pm 0.01 b$ & $0.88 \pm 0.01 \mathrm{a}$ \\
\hline 3. & Millettia ferruginea Hochst & $6.530 .03 b$ & $2.46 \pm 0.01 \mathrm{a}$ & $0.36 \pm 0.01 d$ & $9.13 \pm 0.01 \mathrm{~d}$ & $1.01 \pm 0.00 \mathrm{~b}$ \\
\hline 4. & Erythrina bruce Schweinf & $6.11 \pm 0.01 \mathrm{~b}$ & $2.48 \pm 0.03 \mathrm{a}$ & $0.31 \pm 0.00 \mathrm{~d}$ & $9.10 \pm 0.05 \mathrm{~d}$ & $1.16 \pm 0.01 b$ \\
\hline 5. & Cordia africana Lam. & $7.12 \pm 0.01 \mathrm{c}$ & $3.45 \pm 0.03 \mathrm{a}$ & $0.36 \pm 0.01 d$ & $15.33 \pm 0.02 \mathrm{~g}$ & $1.22 \pm 0.01 \mathrm{~b}$ \\
\hline 6. & Croton macrostachyus (HochstExDel) & $6.50 \pm 0.06 \mathrm{~b}$ & $2.50 \pm 0.06 \mathrm{a}$ & $0.33 \pm 0.02 \mathrm{~d}$ & $8.15 \pm 0.01 \mathrm{c}$ & $0.98 \pm 0.01 \mathrm{ab}$ \\
\hline 8. & Vernonia amygdalina Del. & $5.60 \pm 0.08 \mathrm{a}$ & $3.15 \pm 0.00 \mathrm{c}$ & $0.34 \pm 0.01 d$ & $17.07 \pm 0.06 \mathrm{i}$ & $1.19 \pm 0.05 b$ \\
\hline 9. & Persea americana Mill. & $6.40 \pm 0.12 b$ & $2.63 \pm 0.00 \mathrm{ab}$ & $0.29 \pm 0.01 \mathrm{~d}$ & $18.25 \pm 0.14 \mathrm{j}$ & $0.88 \pm 0.01 \mathrm{a}$ \\
\hline 10. & Mengifera indica $\mathrm{L}$. & $5.20 \pm 0.23 \mathrm{a}$ & $2.74 \pm 0.01 \mathrm{ab}$ & $0.36 \pm 0.02 \mathrm{~d}$ & $16.50 \pm 0.06 \mathrm{~h}$ & $0.75 \pm 0.02 \mathrm{a}$ \\
\hline 11. & Saccharum officinarum L. & $5.35 \pm 0.02 \mathrm{a}$ & $2.31 \pm 0.00 \mathrm{a}$ & $0.29 \pm 0.01 \mathrm{~d}$ & $9.23 \pm 0.03 c$ & $1.35 \pm 0.0 \mathrm{~b}$ \\
\hline 12. & Ricinus communis L. & $5.38 \pm 0.03 \mathrm{a}$ & $2.63 \pm 0.04 \mathrm{ab}$ & $0.29 \pm 0.00 \mathrm{~d}$ & $8.21 \pm 0.01 \mathrm{c}$ & $0.55 \pm 0.06 \mathrm{a}$ \\
\hline 13. & Coffea arabica $\mathrm{L}$. & $6.50 \pm 0.06 \mathrm{~b}$ & $3.21 \pm 0.01 \mathrm{c}$ & $0.32 \pm 0.01 d$ & $7.68 \pm 0.01 b$ & $1.21 \pm 0.02 \mathrm{~b}$ \\
\hline 15. & Phaseolus vulgaris L. & $5.51 \pm 0.29 \mathrm{a}$ & $3.14 \pm 0.02 \mathrm{c}$ & $0.33 \pm 0.01 d$ & $7.68 \pm 0.28 b$ & $1.14 \pm 0.01 \mathrm{~b}$ \\
\hline 16. & Ipomoea batatas (L.) Lam & $5.14 \pm 0.09 \mathrm{a}$ & $2.53 \pm 0.00 \mathrm{a}$ & $0.30 \pm 0.01 d$ & $7.35 \pm 0.03 b$ & $2.18 \pm 0.01 \mathrm{c}$ \\
\hline 17. & Solanum tuberosum L. & $5.33 \pm 0.09 \mathrm{a}$ & $2.71 \pm 0.02 \mathrm{ab}$ & $0.35 \pm 0.00 \mathrm{~d}$ & $6.75 \pm 0.03 \mathrm{a}$ & $1.15 \pm 0.01 \mathrm{~b}$ \\
\hline 18. & Cappsicum annuиm $\mathrm{L}$. & $6.05 \pm 0.48 b$ & $2.47 \pm 0.02 \mathrm{a}$ & $0.30 \pm 0.01 d$ & $14.52 \pm 0.25 f$ & $0.95 \pm 0.03 \mathrm{ab}$ \\
\hline 19. & Rhamnus prinoides L' herit & $5.67 \pm 0.22 \mathrm{a}$ & $2.65 \pm 0.00 \mathrm{ab}$ & $0.34 \pm 0.01 d$ & $16.01 \pm 1.16 \mathrm{~h}$ & $1.20 \pm 0.02 b$ \\
\hline 20. & Dioscorea alata $\mathrm{L}$. & $5.93 \pm 0.08 \mathrm{ab}$ & $2.37 \pm 0.07 \mathrm{a}$ & $0.19 \pm 0.01 \mathrm{a}$ & $17.09 \pm 0.03 \mathrm{i}$ & $1.34 \pm 0.01 \mathrm{~b}$ \\
\hline \multirow[t]{2}{*}{21.} & Colocasia esculenta (L.) Schoot. & $5.23 \pm 0.09 \mathrm{a}$ & $2.78 \pm 0.01 \mathrm{ab}$ & $0.27 \pm 0.01 \mathrm{c}$ & $16.60 \pm 0.12 \mathrm{~h}$ & $2.22 \pm 0.01 \mathrm{c}$ \\
\hline & Mean Total & $5.87 \pm 0.00 \mathrm{ab}$ & $2.73 \pm 0.05 \mathrm{ab}$ & $0.30 \pm 0.01 \mathrm{~d}$ & $12.39 \pm 0.54 \mathrm{ef}$ & $1.10 \pm 0.05 \mathrm{a}$ \\
\hline
\end{tabular}

Key: OC, organic carbon; TN, total nitrogen; AP, available phosphors, K, potassium. Similar letters in columns show not significant difference between plant species at $\mathrm{p}<0.05$.

The physicochemical properties of soil samples of each plant are shown in Table 3. The soil in the study area was slightly acidic with mean $\mathrm{pH}$ of 5.87; mean organic carbon, total nitrogen, available phosphorus and potassium being $2.73,0.30,12.39$ and 1.10 respectively. When individual plant species were considered, all plant species studied significantly affected the rhizosphere soil chemical properties (Table 3). They showed variation in soil $\mathrm{pH}\left(\mathrm{H}_{2} \mathrm{O}\right)$ from 5.0 (acidic) - 7.0 (neutral), whereas soil nitrogen content was in between 0.19 (medium)-0.36\% (high). Similarly, phosphorus (Olson) content varied from the lowest $6.75 \mathrm{mg} \mathrm{P} / \mathrm{kg}$ (Solanum tuberosum) to the highest $18.25 \mathrm{mg} \mathrm{P} / \mathrm{kg}$ (Persea americana). Potassium was highest in the rhizosphere soil of Ipomoea batatas $(2.18 \mathrm{cmol}(+) / \mathrm{kg})$ and the lowest $(0.55$ cmol $(+) / \mathrm{Kg}$ ) was recorded from Prunus africana and Ricinus communis. Organic carbon (OC) content of soil sample fall in between 2.04 (high) to 3.45 (very high).

\subsection{AMF Root Colonization and Spore Density}

The AMF root colonization on the different agroforestry plant species is presented in Table 4. The highest percentage root length colonization (RLC) was recorded in Ensete ventricosum $(86 \%)$ and the lowest in Rhamnus prinoides (53\%) and Colosica esculenta (52\%) respectively (Table 4). All plants were infected with AMF arbuscules and vesicles except Brassica integrifolia and Cucurbita pepo species (data not shown) (Table 4).

In case of vesicle formation, the highest colonization was 
found in Ensete ventricosum and Coffea arabica each $20.33 \%$ followed by Zea mays $18.67 \%$ and Catha edulis (17\%) and the lowest in Persea americana (9.67\%), Mangifera indica (9.33) and Discorea alata (9\%). Considering arbuscule formation, the highest percentage was observed in Ricinus communis (18\%), Persea americana (18\%) followed by Ensete ventricosum (15\%) and Solanum tuberosum (15.33\%). The lowest arbuscular colonization was recorded for Colocasia esculenta (5\%). In most of the records arbuscular and vesicular colonization are not significantly different at $\mathrm{P}<0.05$ level.

The highest number of spore population/100 g dry soil was recorded in the rhizosphere soil of Croton macrostachyus (1066) followed by Catha edulis (1054) and Coffea arabica (995) and the lowest density was recorded in Dioscorea alata (100 spores/100 g soil) (Table 4). From the data (Table 4), it is also observed that the percentage root colonization and spore population do not correlate to each other.

Table 4. Root colonization and spore density of AMF in agroforestry plant species.

\begin{tabular}{|c|c|c|c|c|c|}
\hline \multirow{2}{*}{ S. No } & \multirow{2}{*}{ Plant species } & \multicolumn{4}{|c|}{ AMF Structural Colonization (\%) and spore density } \\
\hline & & $\mathbf{A C}$ & VC & RLC & $\mathrm{SD} / 100 \mathrm{~g}^{-1}$ dry soil \\
\hline 1. & Ensete ventricosum (Welw.) Cheesman) & $15.00 \pm 2.08 \mathrm{ab}$ & $20.33 \pm 0.33 a$ & $85.73 \pm 3.73 a$ & $630.00 \pm 2.90 \mathrm{~d}$ \\
\hline 2. & Catha edulis (vahl.) Forssk. exEndl & $16.67 \pm 2.33 \mathrm{a}$ & $17.00 \pm 1.15 b$ & $84.74 \pm 1.24 \mathrm{a}$ & $1054.00 \pm 53.12 \mathrm{a}$ \\
\hline 3. & Millettia ferruginea Hochst & $11.67 \pm 0.88 \mathrm{~b}$ & $16.67 \pm 1.76 b$ & $83.80 \pm 2.22 \mathrm{ab}$ & $686.00 \pm 2.31 \mathrm{~d}$ \\
\hline 4. & Erythrina brucei Schweinf & $13.67 \pm 1.67 \mathrm{abc}$ & $14.67 \pm 1.33 \mathrm{bc}$ & $80.23 \pm 1.04 \mathrm{~b}$ & $768.00 \pm 39.26 \mathrm{~cd}$ \\
\hline 5. & Cordia africana Lam. & $12.00 \pm 2.31 \mathrm{c}$ & $14.00 \pm 3.00 \mathrm{bc}$ & $72.33 \pm 1.57 \mathrm{c}$ & $880.00 \pm 49.07 \mathrm{c}$ \\
\hline 6. & Croton macrostachyusa (Hochst ExDel.) & $10.00 \pm 0.58 \mathrm{c}$ & $14.33 \pm 0.33 c$ & $64.11 \pm 3.20 \mathrm{~d}$ & $1066.00 \pm 19.63 \mathrm{a}$ \\
\hline 7. & Prunus africana (Hook. f.) Kalkm. & $11.67 \pm 0.33 b$ & $9.67 \pm 0.88 \mathrm{e}$ & $57.67 \pm 2.69 \mathrm{~d}$ & $675.00 \pm 14.43 d$ \\
\hline 8. & Vernonia amygdalina Del. & $7.00 \pm 1.53 \mathrm{c}$ & $13.67 \pm 2.40 \mathrm{cbc}$ & $77.78 \pm 1.91 \mathrm{~b}$ & $600.00 \pm 46.19 \mathrm{~d}$ \\
\hline 9. & Persea americana Mill. & $18.33 \pm 3.84 \mathrm{a}$ & $15.33 \pm 3.18 \mathrm{bc}$ & $80.32 \pm 2.47 \mathrm{ab}$ & $550.00 \pm 21.94 \mathrm{e}$ \\
\hline 10. & Mengifera indica $\mathrm{L}$. & $10.33 \pm 1.20 \mathrm{c}$ & $9.33 \pm 0.88 \mathrm{de}$ & $79.97 \pm 0.77 b$ & $580.00 \pm 69.28 \mathrm{~d}$ \\
\hline 11. & Saccharum officinarum $\mathrm{L}$. & $13.67 \pm 4.18 \mathrm{abc}$ & $16.00 \pm 4.04 \mathrm{ab}$ & $68.87 \pm 2.25 b$ & $625.00 \pm 14.43 \mathrm{~d}$ \\
\hline 12. & Ricinus communis L. & $18.00 \pm 5.69 \mathrm{ab}$ & $14.00 \pm 4.1 \mathrm{bcd}$ & $74.25 \pm 4.31 b c$ & $800.00 \pm 86.60 \mathrm{c}$ \\
\hline 13. & Coffea arabica $\mathrm{L}$. & $11.33 \pm 1.45 \mathrm{c}$ & $20.33 \pm 2.19 \mathrm{a}$ & $80.14 \pm 1.89 b$ & $995.00 \pm 2.89 \mathrm{~b}$ \\
\hline 14. & Zea mays L. & $12.67 \pm 0.33 b$ & $18.67 \pm 1.76 \mathrm{ab}$ & $80.59 \pm 1.82 b$ & $700.00 \pm 46.19 c$ \\
\hline 15. & Phaseolus vulgaris L. & $11.33 \pm 1.67 \mathrm{c}$ & $15.00 \pm 0.58 b$ & $73.27 \pm 1.10 \mathrm{c}$ & $495.00 \pm 83.72 d$ \\
\hline 16. & Ipomoea batatas (L.) Lam & $12.00 \pm 0.58 b$ & $15.00 \pm 0.58 b$ & $70.62 \pm 1.96 \mathrm{c}$ & $665.00 \pm 39.84 d$ \\
\hline 17. & Solanum tuberosum $L$. & $15.33 \pm 5.55 \mathrm{ab}$ & $12.00 \pm 2.52 \mathrm{c}$ & $73.04 \pm 1.63 \mathrm{c}$ & $520.00 \pm 11.55 \mathrm{e}$ \\
\hline 18. & Cappisicum annuит $L$. & $12.33 \pm 1.45 b$ & $10.00 \pm 3.00 \mathrm{dcd}$ & $72.67 \pm 1.76 \mathrm{c}$ & $632.00 \pm 27.71 d$ \\
\hline 19. & Rhamnus prinoides L'herit & $9.67 \pm 1.20 \mathrm{c}$ & $9.67 \pm 0.88 \mathrm{de}$ & $53.33 \pm 5.02 \mathrm{~d}$ & $751.00 \pm 5.20 \mathrm{c}$ \\
\hline 20. & Dioscorea alata $L$. & $11.33 \pm 1.45 \mathrm{c}$ & $9.00 \pm 1.53 \mathrm{de}$ & $60.52 \pm 4.67 \mathrm{~d}$ & $100.00 \pm 2.89 \mathrm{f}$ \\
\hline 21. & Colocasia esculenta (L.) Schoot & $5.00 \pm 1.0 \mathrm{~d}$ & $14.33 \pm 7.17 \mathrm{c}$ & $51.50 \pm 7.17 \mathrm{~d}$ & $660.00 \pm 92.38 \mathrm{~cd}$ \\
\hline
\end{tabular}

Key: AC, Arbuscular Colonization; VC, Vesicular Colonization; RLC, total Root Length Colonization; SD, Spore Density. Similar letters in columns show not significant difference between groups at $\mathrm{p}<0.05$.

Current result in this study reveals that under highest $\mathrm{P}$ and $\mathrm{N}$ concentrations spore density decreased in soils from rhizospheres of some plant species, although the opposite is true for the other species. For soils from the rhizospheres of Persea Americana (P, 19.25; N 0.29), Vernonia amygdalina $(\mathrm{P}, 17.07 ; \mathrm{N} 0.34)$, Mangifera indica $(\mathrm{P}, 16.50 ; \mathrm{N}, 0.36)$, and Dioscorea alata (P, 17.09; N, 0.19) was recorded, $550 \& 80$, $600 \& 78,580 \& 80$ and $100 \& 66$ spores per $100 \mathrm{~g}$ soil and percentage root colonization respectively.

On the other hand for agroforestry plant species with low to medium $\mathrm{P}$ concentration such as Catha edulis $(\mathrm{P}, 7.12 ; \mathrm{N}$, $0.23)$ Croton macrostachyus (P, 8.15; N, 0.33, Coffea arabica $(\mathrm{P}, 7.68 ; \mathrm{N}, 0.32)$ was recorded $1054 \& 85,1066 \& 64$ and $995 \& 80$ spores per $100 \mathrm{~g}$ soil and percentage root colonization respectively. This result indicates that different plant species respond to AMF differently under low, medium and high concentrations of nutrients in their rhizospheres.

Pearson's correlation coefficient showed that spore density was not significantly correlated with soil $\mathrm{pH}$, OC, total nitrogen \& potassium and significant negative correlation with available phosphorus $(\mathrm{r}=-0.346, \mathrm{p}=0.005)$ and electron conductivity $(\mathrm{r}=-0.441, \mathrm{p}=0.00)$ at $\mathrm{P}<0.01$ level (2-tailed). Spore density was also negatively correlated with total nitrogen, but not significantly different.

Pearson's correlation coefficient between root colonization and soil parameters showed that it is negatively correlated to available phosphorus $(\mathrm{r}=-0.324, \mathrm{p}=0.010)$ and potassium $(\mathrm{r}=-$ $0.301, \mathrm{p}=0.017$ ) and significantly different at $\mathrm{P}<0.01$ and $\mathrm{P}<0.05$ level (2-tailed) respectively. It was positive with $\mathrm{pH}$ and total nitrogen but not significantly different and was negative but significantly different between root colonization and organic carbon, and negative but not significantly different in between EC and root colonization.

\subsection{AMF Spore Diversity}

In general 8 different AMF genera were identified (Table 5): Acaulospora, Claroidioglomus, Funneliformis, Glomus, Gigaspora, Rhizophugus, Septoglomus, and Scutellospora of which Glomus and Acaulospora were the dominant genera found in all species. The highest percentage of Glomus was recorded in Coffea arabica (15.27\%) and Ensete ventricosum $(12.68 \%)$ the lowest being recorded in Cappisicum annuum and Colocasia esculenta $(0.29 \%)$. The highest percentage of Acaulospora was recorded in three species; Ensete ventricosum, Coffea arabica, and Zea mays with 14.93\%, $10.85 \%$ and $11.76 \%$ respectively. The highest percentage was 
recorded for Claroideoglomus $(24.18 \%)$ in Croton macrostachyus, Funneliformis (33.9\%) in Ensete ventricosum, Gigaspora (22.94\%) in Catha edulis,
Rhizophugus (28.67\%) in Ensete ventricosum, Septoglomus $(20 \%)$ in Saccharum officinarum, and Scutellospora (16.67\%) in Ensete ventricosum.

Table 5. Percentage AMF diversity in the 21 plant species in Sidama agroforestry.

\begin{tabular}{|c|c|c|c|c|c|c|c|c|c|c|}
\hline \multirow{2}{*}{ S. No } & \multirow{2}{*}{ Plant species } & \multicolumn{9}{|c|}{ Different Genera of AMF (\%) } \\
\hline & & Ac. & Clar. & Fun. & Glo. & Giga. & Rhi. & Sep. & Scut. & Sp. No \\
\hline 1. & Ensete ventricosum (Welw.) Cheesman) & 14.93 & 14.38 & 33.9 & 12.68 & 17.65 & 28.67 & 13.33 & 16.67 & 8 \\
\hline 2. & Catha edulis (vahl.) Forssk. exEndl & 3.18 & - & 10.17 & 9.8 & 22.94 & 16 & - & 2.38 & 6 \\
\hline 3. & Millettia ferruginea Hochst & 4.07 & 14.38 & 11.86 & 11.82 & 2.35 & 12.67 & 6.67 & 5.95 & 8 \\
\hline 4. & $\begin{array}{l}\text { Erythrina } \\
\text { brucei Schweinf }\end{array}$ & 4.07 & 5.23 & 16.95 & 2.31 & 3.53 & 3.33 & - & 1.19 & 7 \\
\hline 5. & Cordia africana Lam. & 3.62 & 5.23 & 5.08 & 0.86 & 3.53 & 0.67 & - & 2.38 & 7 \\
\hline 7. & Prunus africana. (Hook. f.) Kalkm & 3.17 & 1.31 & - & 1.73 & 1.18 & 6 & - & 4.76 & 6 \\
\hline 8. & Vernonia amygdalina Del. & 2.71 & 2.61 & 3.39 & 4.9 & 1.18 & 6 & 13.33 & 4.76 & 8 \\
\hline 9. & Persea americana Mill. & 4.07 & - & - & 1.73 & 1.18 & 2.67 & - & 3.57 & 5 \\
\hline 10. & Mengifera indica $\mathrm{L}$. & 1.36 & 1.31 & - & 3.17 & - & 2 & - & 3.57 & 5 \\
\hline 11. & Saccharum officinarum L. & 3.62 & 2.61 & - & 3.46 & 0.58 & 3.33 & 20 & 7.14 & 7 \\
\hline 12. & Ricinus communis L. & 3.18 & - & 3.39 & 1.44 & 2.53 & 0.67 & - & 3.57 & 6 \\
\hline 13. & Coffea arabica $\mathrm{L}$. & 10.85 & 17.64 & - & 15.27 & 17.65 & 2 & - & 13.1 & 6 \\
\hline 15. & Phaseolus vulgaris L. & 4.07 & 1.31 & 3.39 & 1.44 & 2.53 & 3.33 & - & 4.76 & 7 \\
\hline 16. & Ipomoea batatas (L.) Lam & 2.26 & 3.92 & - & 2.59 & 2.94 & 2 & - & 3.57 & 6 \\
\hline 17. & Solanum tuberosum L. & 1.8 & - & 3.39 & 1.73 & 1.76 & - & 13.33 & 5.95 & 6 \\
\hline 18. & Cappisicum annuит $\mathrm{L}$. & 3.18 & 1.31 & - & 0.29 & - & - & - & - & 3 \\
\hline 19. & Rhanmmu sprinoides L'herit & 2.26 & 1.96 & 1.69 & 0.58 & - & - & - & - & 4 \\
\hline 20. & Dioscorea alata $\mathrm{L}$. & 1.36 & 1.31 & - & 0.86 & 1.18 & - & 6.67 & 1.19 & 6 \\
\hline \multirow[t]{2}{*}{21} & Colocasia esculenta (L.) School. & 0.45 & 1.31 & - & 0.29 & 1.18 & - & - & - & 4 \\
\hline & Mean & 9.91 & 7.29 & 2.814 & 16.29 & 8.05 & 6.95 & 0.71 & 3.90 & \\
\hline
\end{tabular}

Key: Ac., Acaulospora; Claro., Claroidioglomus; Fun., Funneliformis; Glo., Glomus; Giga., Gigaspora; Rhi., Rhizophugus; Sep., Septoglomus; Scut., Scutellospora.

In this study, observed Plant species density (Figure 1) in the agroforestry does not induced consistent spore formation and percentage root colonization values in all plant species. Colocassia esculenta with its relative abundance value of $0.1 \%$ (982) showed percentage colonization of $52 \%$, spore density of 660 and for Dioscorea alata with its relative abundance value of $0.05 \%$ (511) was recorded root colonization of $61 \%$, more than Colocasia esculenta (Figure 1) and the least spore density of 100 spore/ $100 \mathrm{~g}$ soil.

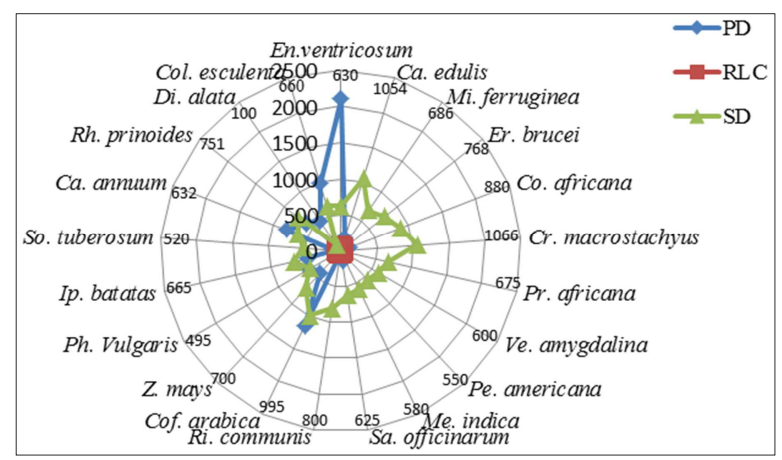

Figure 1. Effect of plant species density on root colonization and spore density.

Key: PD, plant density; RLC, total root length colonization; SD, Spore density, En, Ensete; Ca, Catha; Mi, Millettia; Er, Erythrina; Co, Cordia; Cr, Croton; Pr, prunus; Ve, Vernonia; Pe, Persea; Me, Mengifera; Sa, Saccharum; Ri, Ricinus; Cof, Coffee; Z, Zea; Ph, Phaseolus; Ip, Ipomoea; So, Solanum; Ca, Cappisicum; Rh, Rhamnus; Di, Discorea; Col, Colocasia
On the other hand for species with the highest value of percentage abundance $0.22 \%$ (2107) in Ensete ventricosum, was recorded the highest percentage colonization (86\%) and medium number of spore density (630 spores/100-g dry soil). For Croton macrostachyus with percentage abundance value of about $0.008 \%$ (75), was recorded 1066 spores/100 g soil and 64.11 percentage root colonization. The next highest spore density (1054 100-1 g soil) and root colonization (85\%) was recorded for perennial crop Catha edulis with its percentage abundance value of about $0.02 \%$ (188), followed by Coffee arabica, 995 spores $100-1 \mathrm{~g}$ soil and $80 \%$ colonization with its abundance value of $0.12 \%$ (1147) respectively. This indicates that in some plant species (e.g. Ensete ventricosum) density decreased the spore production but in some other plant species such as Coffee arabica plant species density has increased spore production.

\section{Discussion}

The effects of plant species density and its associated soil chemical properties in Sidama agroforestry homegardens were studied to determine their influence on AMF diversity, spore density and root colonization. The arbuscular mycorrhizal fungi spore population and root colonization pattern varied in different plant species in Sidama homegarden agroforestry systems. The study on diversity of AMF in relation to soil parameters and plant species density did not show significant differences in AMF diversity indices (Shannon-Weaver diversity index, 
Simpson's Index of Diversity (data not shown)) due to plant species density and soil physical and chemical properties. However, there were differences in AMF spore density and root colonization between plant species. Shifts in AMF species composition with increasing or decreasing plant species density may be explained in part by differential responses of individual AMF species to individual host plant species and edaphic factors in the rhizospheres of each plant species.

According to [20], three mechanisms have been proposed to account for plant density-dependent regulation of mycorrhizal colonization. According to their report, higher plant together with higher root density causes, a) an increase in overlap of phosphorus depletion zone, b) a competition for light results in less carbohydrate available for mycorrhizal fungi and c) an increase in cost-benefit ratio of mycorrhizal colonization. As plant density increase, competition for light increases and photosynthesis per plant declines and plants become limited more by carbon than by $\mathrm{P}$ reducing the root colonization. However, in some cases, increasing plant density has been associated with increasing AMF colonization $[1,11]$.

Most of the plants included in this study are multiple purpose trees and perennial crops with course root systems. The variation in the percentage of colonization in the roots and the AM population in the rhizosphere soils of different plants recorded in the present study, therefore might explain the generally held view that plants with coarse roots gain more AMF [22] compared to those with fine roots. These differences might be due to the presence of diverse type of AMF in the rhizosphere soils of individual plant species or might be a manifestation of greater host susceptibility to AMF [23].

In this study 8 different AMF genera were identified: Acaulospora, Claroidioglomus, Funneliformis, Glomus, Gigaspora, Rhizophugus, Septoglomus, and Scutellospora of which Glomus and Acaulospora were the dominant genera found in all species. This is not surprising since it was previously shown that Glomus and Acaulospora species are most abundant among the glomeromycotan genera in tropical areas [3, 14, 37, 41]. Glomus species is widely distributed regardless of the type and intensity of disturbance in the different ecosystems, whereas Acaulospora is dominant in least disturbed agro ecosystems [36].

In our study, the total spore density, in general, did not correlate with mycorrhizal colonization, possibly because of the presence of a diverse population of AM fungal species and it could also be due to the fact that there are AMF species that rely more on extensive formation of hyphal networks instead of survival through spore formation as primary infective propagules.

The relationship between spore numbers and mycorrhizal colonization has been found positive by several workers [15] but negative by others [21]. Some workers have also found no relationship between mycorrhizal colonization and spore density of AMF [9]. The factors like edaphic or climatic condition; host fungus compatibility, root properties and soil microorganisms might influence the abundance of spore population and mycorrhizal associations with a particular tree species.
It is noticeable in the present study that the wide spread presence of Glomus and Acaulospora in the rhizospheres of selected plants, makes them favorable fungi for mass multiplication as well as seedling inoculation for their better establishment. The present survey of AM fungi on Sidama agroforestry plant species reveals that AM fungi are common, occurring in 21 of the 23 plant species examined. However, when establishing new agroforestry practices the tree species must possess adequate amounts of mycorrhizal colonization at the planting stage in order to survive better and perform well in adverse agroforestry sites. More studies are needed to select the suitable indigenous AM fungal strains for the production of quality plant and expanding the awareness of the role of AMF in agroforestry systems to the small holder peasants for better organic and sustainable production should be initiated.

\section{Conclusion}

The investigation reveals that AM fungi are common, occurring in 21 out of 23 plant species examined. The study also demonstrated the influence of different plant densities on the diversity of arbuscular mycorrhizal fungi. As to the dependency of AMF on soil parameters, plants exhibited variable patterns; some with high concentration of $\mathrm{P}$ showed lower spore density and root colonization, while others shows the opposite phenomena. Glomus and Acaulospora were dominant in this study. They could be used for mass multiplication as well as seedling inoculation for better establishment of major trees and perennial crops which can also serve as inoculums sources. Mycorrhization of agroforestry plants has gained considerable attention over the last few years because of their role as biofertilizers for improving host growth. More studies are needed to select the suitable indigenous AM fungal strains for the production of quality plant and expand the awareness of the role of mycorrhiza in agroforestry systems to the small holder farmers.

\section{Acknowledgment}

We would like to acknowledge Hawassa College of Teacher Education for financial and logistic supports; Department of Microbiology, Cellular and Molecular Biology, Addis Ababa University and College of agriculture, Hawassa University for their support with chemicals and laboratory equipments.

\section{References}

[1] Allsopp, N. and Stock W. F. (1992). Density dependent interactions between VA mycorrhizal fungi and even-aged seedlings of two perennial Fabaceae species. Oecologia, 91, 281-287. doi: 10.1007/BF00317797.

[2] Black, C., Evans, A. D., White, J. L., Ensminger, L. E. and Clark, F. E. (1965). Methods of Soil Analysis Part 1. Physical and Mineralogical Properties Including Statistics of Measurement and Sampling, American Society of Agronomy, Madison, Wis, USA. 
[3] Blaszkowski, J. (1989). The occurrence of the Endogonaceae in Poland. Agril. Ecosy. Envin., 29: 45-50.

[4] Bolan, N. S., Robson, A. D. and Barrow, N. J. (1987). Effects of vesicular-arbuscular mycorrhiza on the availability of iron phosphates to plants. Plant Soil 99: 401-410.

[5] Bremner, J. M. and Mulvaney, S. C. (1982). "Nitrogen-Total," in Methods of Soil Analysis, A. L. Page, Eds., vol. 2, pp. 595624, American Society of Agronomy, Madison, Wis, USA.

[6] da Silva Sousa, C., Cezar Menezes, R. S., de Sá Barreto Sampaio, E. V., de Sousa Lima, F. and Costa Maia, L. (2013). Arbuscular mycorrhizal fungi within agroforestry and traditional land use systems in semi-arid Northeast Brazil. Acta Scient. Agron., 35: 307-314.

[7] Dalpe, Y., Plenchette, C. and Gueye, M. (2000). Glomales species associated with surface and deep rhizosphere of Faidherbia albida in Senegal. Mycorrhiza, 10, 125-129.

[8] Demir, S., Kaya, I., Şavur, O. B. and Özkan, O. U. (2008). Determination of Arbuscular-Mycorhizal Fungus (AMF) from the Plants Belonging to Gramineae Family in Van Province, Yüzüncü Y1l University, Faculty of Agriculture, J. Agric. Sci., 18 (2): 103-111.

[9] Diaz, G. and Honrubia, M. (1994). A mycorrhizal survey of plants growing on mine wastes in Southern Spain. Arid Soil Res. Rehabilitation, 8: 59- 68 .

[10] Emiru, Birhanea, Thomas, W. K., Frank, J. S. and Frans, B. (2010). Arbuscular mycorrhizal associations in Boswellia papyrifera (frankincense-tree) dominated dry deciduous woodlands of Northern Ethiopia. Forest Ecology and Management, 260: 2160-2169.

[11] Eissenstat, D. M. and Newman, E. I. (1990). Seedling establishment near large plants: effects of vesicular-arbuscular mycorrhizas on the intensity of plant competition. Funct Ecol., 4, 95-99.

[12] Fisher, R. A. and Yates, F. (1970). In Statistical tables for biological, agriculture and medical research. $6^{\text {th }}$ ed. Davien: Hafner.

[13] Gerdemann, J. W. and Nicolson, T. H. (1963). Spores of mycorrhizal Endogone species extracted from soil by wet sieving and decanting. Transactions of the British Mycological Society, 46, 235-244.

[14] Gerdemann, J. W. and Trappe, M. J. (1974). The Endogonaceae in the Pacific Northwest. Mycologia Memoir, No. 5. The New York Botanical Garden, New York. Pp 76.

[15] Giovannetti, M and Nicolson, H. T. (1983). Vesiculararbuscular Mycorrhizas in Italian sand dunes. Trans. Br. Mycol. Soc., 80: 552-555.

[16] Jasper, D. A. (1992). Management of mycorrhizas in revegetation. In: Robson, A. D.; L. K. Abbott and N. Malajczuk (eds.), Proceedings of International Symposium on Management of Mycorrhizas in Agriculture, Horticulture and Forestry.

[17] Jefwa, J. M., Sinclair, R. and Maghembe, J. A. (2006). Diversity of glomale mycorrhizal fungi in maize/sesbania intercrops and maize monocrop systems in Southern Malawi, Agroforestry systems, 67: 107-114.

[18] Jones, B. J. J. (2001). Laboratory Guide for Conducting Soil Tests and Plant Analysis, CRC press, LLC.
[19] Li, X. L., Marschnerm, H. and George, E. (199). Extension of the phosphorus depletion zone in VA mycorrhizal white clover in a calcareous soil. Plant and Soil, Vol: 135, p: 41-48.

[20] Koide, R. T. and Dickie, I. A. (2002). Effects of mycorrhizal fungi on plants populations. Plant Soil 244, 307-317. doi: 10.1023/A:1020204004844.

[21] Louis, L. and Lim G. 1987. Spore density and root colonization of vesicular-arbuscular Mycorrhizas in tropical soil. Trans. Br. Mycol. Soc., 88: 207-212.

[22] Mahmud, R. M., Mridha, U. A., Osman, T. K., Xu, L. H. and Umemura, H. (1999). Relationship between edaphic factors and arbuscular mycorrhizal fungi in soils of rubber plantation. The $207^{\text {th }}$ Annual Meeting of Japanese Society of Crop Science, April 2-3, 1999, Tokyo. Jap. J. Crop Sci., 68 (Extra 1): 244-245.

[23] Mehrotra, V. S. 1998. Arbuscular mycorrhizal association of plants colonizing coal mine spoils in India. J. Agril. Sci., Cambridge. 130: 123-133.

[24] Millat-e-Mustafa, M. (1997). Tropical Homegardens: An overview. In: Alam, M. K., F. U. Ahmed and A. M. Ruhul Amin (eds.), Agroforestry: Bangladesh Perspective, BARC. Pp 18-33.

[25] Olsen, S. R. and Dean L. A. (1965). "Phosphorous," in Methods of Soil Analysis Part 2: Chemical and Microbiological Properties, C. A. Black, Ed., vol. 9, pp. 10351049, American Society of Agronomy, Madison, Wis, USA.

[26] Ortaş, İ. 2002. Do Plants depend on mycorrhizae in terms of nutrient requirement?, International conference on sustainable land use and management. Çanakkale.

[27] Phillips, J. M. and Hayman D. S. (1970). Improved procedures for clearing roots and staining parasitic and vesiculararbuscular mycorrhizal fungi for rapid assessment of infection. Trans. Br. Mycol. Soc., 55: 158-161.

[28] Power M. E. and Mills L. S. (1995). The keystone cops meet in Hilo. Tree 10, 182-184.

[29] Raintree, J. B. (1997). Agroforestry concepts. In: Alam, M. K.; F. U. Ahmed and A. M. Ruhul Amin (eds.), Agroforestry: Bangladesh Perspective, BARC. Pp 1-17.

[30] Rhodes, L. H. (1980). The use of mycorrhizae in crop production systems. Outlook on Agriculture, 10 (6): 275 - 281.

[31] Roy, I. (1997). Cropland Agroforestry: The experience of the village and farm forestry programme. In: Alam, M. K.; F. U. Ahmed and A. M. Ruhul Amin (eds.), Agroforestry: Bangladesh Perspective, BARC. pp. 98-11.

[32] Schenck, N. C. and Pérez, Y. (1990). Manual for the Identification of VA Mycorrhizal Fungi. SynergisticPublications, Gainesville, Florida.

[33] Schnitzer, M. 1982. "Total carbon, organic matter and carbon," in Methods of Soil Analysis-Part 2, Agronomy Monograph, A. L. Page, R. H. Miller, and D. R. Keeney, Eds., vol. 9, pp. 539- 577, American Society of Agronomy, Madison, Wis, USA, ${ }^{\text {nd }}$ edition.

[34] Sieverding, E. 1991. Vesicular-arbuscular mycorrhiza management in tropical agro systems. German Technical cooperation (GTZ) Eschborn, pp 371. ISBN 3880854629.

[35] Smith, S. E. and Read, D. J. (1997). Mycorrhizal symbiosis, $2^{\text {nd }}$ edn. Academic Press, London, U. K. 
[36] Snoeck, D., Abolo, D. and Jagoret, P. (2010). Temporal changes in VAM fungi in the cocoa agroforestry systems of central Cameroon. Agroforestry Syst., 78: 323-328.

[37] Talukdar, N. C. and Germida, J. J. (1993). Occurrence and isolation of vesicular-arbuscular mycorrhizae in cropped field soils of Saskatchewan. Can. J. Microbial., 39: 576-586.

[38] Verbruggen, E. and Toby Kiers, E. (2010). Evolutionary ecology of mycorrhizal functional diversity in agricultural systems. Evolutionary Appl., 3: 547-560.

[39] Wang, F. Y., Liu, R. J. and Lin, X. G. (2004). Arbuscular mycorrhizal status of wild plants in salin-alkaline soils of the yellow river delta. Mycorrhiza, 14, 133-137.

[40] Zebene Asfaw, (2003). Tree species diversity, Top soil conditions and Arbuscular mycorrhizal Association in the Sidama Traditional agroforestry land use, southern Ethiopia, Doctorial Thesis Department of Forest management and products, SLU. Acta Universitatis Sueciae. Silverstria, p. 263.

[41] Zerihun Belay, Fassil Asefa, and Mauritz V. (2013). Diversity and abundance of arbuscular mycorrhizal fungi associated with acacia trees from different land use systems in Ethiopia. African Journal of Microbial Research, 7 (48), pp. 550. 